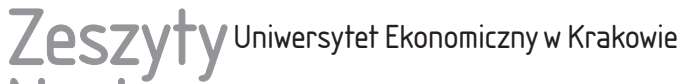 Naukowe
}

\section{Znaczenie regionalnych komisji orzekających w systemie odpowiedzialności za naruszenie dyscypliny finansów publicznych}

\section{Streszczenie}

Zagadnienia prezentowane $\mathrm{w}$ artykule dotyczą działalności regionalnych komisji orzekających (RKO) w systemie odpowiedzialności za naruszenie dyscypliny finansów publicznych. Przeprowadzono analizę aktywności RKO w Polsce, biorąc pod uwagę przypisane czyny naruszeń dyscypliny finansów publicznych, złożone wnioski o ukaranie, odstępstwa od wymierzenia kary, orzeczenia o uniewinnieniu, a także werdykty o ukaraniu obwinionego.

Celem artykułu jest przedstawienie wybranych aspektów działalności RKO. Osiągnięcie tak sformułowanego celu wymagało przeprowadzenia studiów literatury przedmiotu, regulacji prawnych, a także analizy sprawozdań Głównej Komisji Orzekającej w Sprawach o Naruszenie Dyscypliny Finansów Publicznych. Badaniem objęto lata 2011-2016. Wyniki pozwoliły ukazać zróżnicowaną aktywność poszczególnych RKO w Polsce.

Słowa kluczowe: samorząd terytorialny, dyscyplina finansów publicznych, nieprawidłowości, regionalna komisja orzekająca.

Klasyfikacja JEL: H61, M19, H72. 


\section{Wprowadzenie}

Racjonalne gospodarowanie środkami publicznymi przesądza o sprawności działania współczesnego państwa, a mają na nie wpływ uwarunkowania natury prawnej, ekonomicznej (finansowej) i socjologicznej, a także czynniki polityczne. Prawidłowe prowadzenie gospodarki finansowej jednostek sektora finansów publicznych wymaga bezwzględnego respektowania licznych reguł i zasad budżetowych. Przeprowadzanie operacji o charakterze ekonomiczno-finansowym, obejmujących gromadzenie dochodów i przychodów, a następnie ich legalne rozdysponowanie, wymaga umiejętnego zorganizowania struktur, procedur oraz efektywnych mechanizmów kontroli. Działania te wpisują się w nurty współczesnych metod zarządzania w sektorze publicznym. Pozwalają one efektywnie realizować bądź udoskonalać dany zakres czynności, gwarantując osiągnięcie założonych celów.

Ważną rolę w zarządzaniu środkami publicznymi ma odegrać koncepcja kontroli zarządczej, wprowadzona do administracji publicznej w 2010 r. Zakłada się w niej przede wszystkim konieczność diagnozowania i oceny ryzyka naruszenia dyscypliny finansów publicznych.

Utrzymanie reżimu w zarządzaniu finansami publicznymi jest istotne w kontekście kryzysów finansowych, które dotknęły niektóre państwa europejskie. Można zaryzykować stwierdzenie, że problemy finansowe sektorów publicznych tych państw są wynikiem zaniedbań w zakresie utrzymywania dyscypliny finansów publicznych, oczywiście uwzględniając trochę szersze znaczenie tego pojęcia (Kot 2011, s. 5). Ustaloną dla określonych warunków ustrojową organizacją finansów publicznych trzeba dobrze zarządzać, wprowadzając odpowiedni system odpowiedzialności za podejmowanie (lub zaniechanie) czynności związanych z gospodarowaniem finansami państwa (Szołno-Koguc 2015, s. 22). W dokonywaniu oceny stopnia szkodliwości naruszenia dyscypliny finansów publicznych istotną rolę odgrywają wyspecjalizowane organy administracji publicznej, w tym regionalne komisje orzekające (RKO), należy jednak sprawdzić, czy rzeczywiście ten odrębny aparat orzeczniczy jest wystarczająco skuteczny, aby zapewnić legalne i efektywne zarządzanie finansami państwa.

Celem artykułu jest przedstawienie wybranych zagadnień dotyczących działalności RKO. Przeprowadzono studia literatury przedmiotu, regulacji prawnych, a także analizę sprawozdań Głównej Komisji Orzekającej w Sprawach o Naruszenie Dyscypliny Finansów Publicznych (GKO). Zaprezentowano także wybrane przykłady orzecznictwa GKO. Badanie dotyczyło lat 2011-2016. Wyniki pozwoliły ukazać zróżnicowaną aktywność poszczególnych RKO w Polsce. 


\section{Dyscyplina finansów publicznych}

W zapewnieniu sprawnego działania systemu finansów publicznych, czego wyrazem jest przede wszystkim jak najlepsze wykorzystanie środków publicznych, a więc zaspokajanie potrzeb lokalnych, regionalnych i ogólnokrajowych, ważne jest to, w jaki sposób środki publiczne są gromadzone oraz wydatkowane (Owsiak 2013, s. 126). Jednym z instrumentów mających wpływ na ograniczenie nieprawidłowości w działaniu gospodarki finansowej jest nałożenie odpowiedzialności za naruszenie dyscypliny finansów publicznych.

Zagadnienia dotyczące dyscypliny budżetowej zostały po raz pierwszy ujęte w dekrecie o uchwaleniu i wykonaniu budżetu państwa z 1952 r. (Dekret z dnia 17 grudnia 1952 r....). Zgodnie z przepisami zawartymi w tym dokumencie minister finansów oraz służby finansowe prezydiów rad narodowych byli zobowiązani do przestrzegania dyscypliny budżetowej, $w$ tym akcie prawnym nie zdefiniowano jednak, na czym ma ono polegać. $Z$ kolei w uchwale o zasadach i trybie wykonania budżetu państwa (Uchwała nr 23 Rady Ministrów z dnia 29 kwietnia 1953 r....), wydanej na podstawie delegacji sformułowanej we wspomnianym dekrecie, wskazywano konieczność egzekwowania odpowiedzialności służbowej, dyscyplinarnej i materialnej osób winnych dokonywania wydatków wykraczających poza ramy kredytów budżetowych (Lipiec-Warzecha 2012, s. 30).

Bardziej szczegółowe zasady normujące kwestie dotyczące dyscypliny budżetowej zostały określone w przepisach ustawy o prawie budżetowym z $1958 \mathrm{r}$. (Ustawa z dnia 1 lipca 1958 r....). Co istotne, wyodrębniono w niej dział IV, zatytułowany Dyscyplina budżetowa. Zamieszczono w nim jednak tylko pięć artykułów zawierających zapisy dotyczące regulacji w zakresie dyscypliny budżetowej (art. 44-48). Podkreślano znaczenie ponoszenia odpowiedzialności służbowej i karnej podczas opracowywania i wykonywania budżetu państwa, a także budżetów terenowych. Przestrzeganie prawa budżetowego z $1958 \mathrm{r}$. wymagało absolutnego respektowania reguł w zakresie działania gospodarki budżetowej oraz poszanowania procedur dotyczących ustalania etatów i stawek funduszu płac. Mimo że prawo budżetowe zawierało oddzielny rozdział poświęcony zagadnieniom dyscypliny budżetowej, to w przepisach tego aktu prawnego w żaden sposób jej nie zdefiniowano.

W kolejnych latach zagadnienia i poszczególne delikty dotyczące dyscypliny budżetowej były ujmowane w następujących aktach prawnych: w prawie budżetowym z 1970 r. (7 deliktów), z 1984 r. (12) oraz z 1991 r. (13) (Ustawa z dnia 25 listopada 1970 r...., Ustawa z dnia 3 grudnia 1984 r. ..., Ustawa z dnia 5 stycznia 1991 r....). Duże zmiany w zakresie dyscypliny budżetowej wprowadzono wraz $\mathrm{z}$ wejściem $\mathrm{w}$ życie przepisów ustawy o finansach publicznych z 1998 r. (Ustawa z dnia 26 listopada 1998 r. ...). Nowatorskie rozwiązania zawarte 
w dziale $\mathrm{V}$ tej ustawy polegały na znacznym rozszerzeniu katalogu czynów (19 deliktów) wskazujących na naruszenie dyscypliny finansów publicznych. Prawodawca zrezygnował z posługiwania się pojęciem dyscypliny budżetowej, wprowadzono natomiast termin „dyscyplina finansów publicznych”.

Odrębną regulację prawną, w której kompleksowo omówiono zasady i zakres odpowiedzialności za naruszenie dyscypliny finansów publicznych, Sejm RP uchwalił w 2004 r. (Ustawa z dnia 17 grudnia 2004 r. ...). Ustawa zaczęła obowiązywać 5 lipca $2005 \mathrm{r}$. W porównaniu z wcześniejszymi rozwiązaniami prawnymi znacznie rozszerzono zakres odpowiedzialności podmiotowej, opisany w art. 4 i 4a. Uszczegółowiono także katalog naruszeń dyscypliny finansów publicznych. Wprowadzenie w systemie finansów pionierskich rozwiązań - koncepcji kontroli zarządczej oraz instytucji audytu wewnętrznego - wymagało uzupełnienia ustawy o zapisy dotyczące odpowiedzialności kierownika jednostki za niewykonanie lub nienależyte wykonanie obowiązków w tym zakresie (art. 18a i 18c).

W literaturze przedmiotu dyscyplina finansów publicznych jest różnie definiowana w zależności od dyscypliny naukowej, w prawie, ekonomii i finansach inaczej bowiem podchodzi się do samej istoty naruszeń tej dyscypliny. Termin ten jest często stosowany w regulacjach prawnych, a mimo to nie został on jednoznacznie zdefiniowany. Zwykle dyscyplina finansów publicznych jest rozumiana jako obowiązek przestrzegania określonych w prawie zasad legalności i gospodarności w prowadzeniu gospodarki finansami publicznymi, w szczególności działalności budżetowej (Chojna-Duch 2003, s. 124). Spotyka się także objaśnienia, w których dyscyplina finansów publicznych polega na przestrzeganiu wszelkiego rodzaju norm prawnych obowiązujących jednostki dysponujące środkami budżetowymi, określających zasady i tryb pobierania dochodów i dokonywania wydatków publicznych (Ziółkowska 2012, s. 318).

Na podstawie przeprowadzonego przeglądu definicji dyscyplinę finansów publicznych i związany z nią zakres odpowiedzialności można określić jako systemową asekurację w kontekście prawidłowego gospodarowania finansami publicznymi oraz efektywnego zarządzania mieniem państwowym. Jest to szczególny rodzaj odpowiedzialności, ponieważ podczas rozpatrywania konkretnego czynu uwzględnia się nie tylko wymogi ustalone w przepisach prawa, lecz także stopień szkodliwości tego czynu dla stanu finansów publicznych, którego ustalenie jest obowiązkiem prawnym właściwego organu orzekającego. Naruszenie dyscypliny finansów publicznych nie musi wiązać się z powstaniem szkody w majątku Skarbu Państwa lub innego podmiotu publicznego (Malinowska-Misiąg i Misiąg 2006, s. 675 i nast.), jest nim już samo odstępstwo od reguł funkcjonowania sektora publicznego, nawet jeśli nie spowodowało ono realnych negatywnych skutków. Jednym z aspektów wyróżniających ten szczególny rodzaj odpowiedzialności jest to, że jest ona rozpatrywana zupełnie niezależnie od odpowiedzialności z tytułu 
naruszenia przepisów kodeksu karnego, karno-skarbowego oraz pragmatyki służbowej (poza ustawowymi wyjątkami).

\section{Delikty naruszeń dyscypliny finansów publicznych}

Nie wszystkie wypadki naruszenia prawa w gospodarowaniu publicznymi środkami finansowymi wyczerpują znamiona naruszeń dyscypliny finansów publicznych. O jej naruszeniu można mówić jedynie wówczas, gdy doszło do popełnienia określonego czynu wskazanego w przepisach prawa. Na podstawie wykładni przepisów Ustawy z dnia 17 grudnia 2004 r. oraz poglądów utrwalonych w nauce prawa sformułowano definicję czynu kwalifikowanego jako naruszenie dyscypliny finansów publicznych, którym jest wyłącznie zachowanie się osoby fizycznej, nie osób prawnych ani innych jednostek kolektywnych - zgodnie z zasadą societas delinquere non potest (Lipiec-Warzecha 2012, s. 306).

Szczegółowe zestawienie czynów skutkujących pociągnięciem do odpowiedzialności za naruszenie dyscypliny prawodawca zawarł w treści art. 5-18c ustawy (Ustawa z dnia 17 grudnia 2004 r. ...). Jest to katalog zamknięty. Obejmuje on kilkanaście czynów, wśród których wyszczególniono czyny bezwarunkowo karne, a także takie delikty, w wypadku których penalizacja jest względna - zależna od dodatkowych warunków (zob. Chojna-Duch 2003, s. 125). Należy dodać, że podmiotom niezaliczanym do sektora finansów publicznych, które dysponują publicznymi środkami finansowymi przekazanymi na dofinansowanie lub sfinansowanie realizacji zadań publicznych, w wypadku stwierdzenia niezgodności w ich wykorzystaniu lub dysponowaniu nimi (np. niestosowania przepisów Ustawy z dnia 29 stycznia 2004 r.) mogą być przypisane jedynie niektóre czyny karalne naruszające dyscyplinę finansów publicznych. Jest to nieliczna grupa, której opis zamieszczono w treści art. 5, 9, 13 oraz art. 17 Ustawy z dnia 17 grudnia 2004 r. Z orzecznictwa GKO wynika, że wyłącznie jeden czyn może stanowić jeden przypadek naruszenia dyscypliny finansów publicznych (Orzeczenie GKO z 28 lutego 2011 r....).

W tabeli 1 przedstawiono szczegółowe dane liczbowe dotyczące poszczególnych czynów naruszających dyscyplinę finansów publicznych. W latach 2011-2016 największą liczbę czynów skutkujących pociągnięciem do odpowiedzialności z tytułu naruszenia dyscypliny finansów publicznych odnotowano w 2012 r. (1633), najmniejszą zaś w 2016 r. (926). W ujęciu przedmiotowym przeważały czyny popełnione $\mathrm{w}$ związku z nieprawidłowościami powstałymi w wyniku naruszenia art. 11 Ustawy z dnia 17 grudnia 2004 r. (1105). W poszczególnych latach czyny te wynosiły: 10\% w 2011 r., 19\% w 2012 r., 18\% w 2013 r. oraz 16\% w 2016 r. Równie duża liczba naruszeń nastąpiła na skutek popełnienia czynu polegającego 
Tabela 1. Liczba czynów naruszających dyscyplinę finansów publicznych odnotowanych w latach 2011-2016

\begin{tabular}{|l|c|c|c|c|c|c|}
\hline \multicolumn{1}{|c|}{$\begin{array}{c}\text { Podstawa prawna przypisania } \\
\text { popełnienia czynu }\end{array}$} & 2011 & 2012 & 2013 & 2014 & 2015 & 2016 \\
\hline art. 5, ust. 1, pkt 1 i 2 & 68 & 35 & 21 & 31 & 46 & 26 \\
\hline art. 5, ust. 1, pkt 3 & - & 10 & 5 & 12 & 6 & 9 \\
\hline art. 6 & 72 & 52 & 38 & 19 & 15 & 24 \\
\hline art. 7 & 2 & 7 & 4 & 9 & 1 & 4 \\
\hline art. 8 & 55 & 85 & 43 & 35 & 39 & 35 \\
\hline art. 9 & 85 & 60 & 52 & 69 & 59 & 39 \\
\hline art. 10 & 22 & 5 & 7 & 5 & 1 & 1 \\
\hline art. 11 & 158 & 321 & 204 & 136 & 141 & 145 \\
\hline art. 12 & 1 & - & - & 2 & 2 & - \\
\hline art. 13, pkt. 1-5,9 & 24 & 5 & - & 1 & - & - \\
\hline art. 13,pkt 6-8 & - & 3 & 14 & 14 & 24 & 24 \\
\hline art. 14 & 96 & 68 & 54 & 39 & 51 & 26 \\
\hline art. 15 & 119 & 151 & 88 & 71 & 88 & 96 \\
\hline art. 16 & 48 & 24 & 20 & 13 & 29 & 15 \\
\hline art. 17, ust. 1 & 446 & 96 & 41 & 38 & 47 & 59 \\
\hline art. 17, ust. 1b & - & 163 & 119 & 68 & 42 & 54 \\
\hline art. 17, ust. 1c & - & 55 & 51 & 32 & 52 & 33 \\
\hline art. 17, ust. 2 & - & 8 & 11 & 1 & 3 & 1 \\
\hline art. 17, ust. 3 & - & 6 & 12 & 7 & 3 & 2 \\
\hline art. 17, ust. 4 & - & 25 & 11 & 8 & 7 & 7 \\
\hline art. 17, ust. 5 & - & 2 & 1 & 2 & 1 & 1 \\
\hline art. 17, ust. 6 & - & - & - & - & - & - \\
\hline art. 17a & - & - & - & 3 & 9 & 6 \\
\hline art. 18, pkt 1 & - & 1633 & 1126 & 915 & 981 & 926 \\
\hline art. 18, pkt 2 & - & 112 & 104 & 81 & 107 \\
\hline art. 18a & - & 161 & 140 & 155 & 126 \\
\hline art. 18b & - & 9 & 6 & 6 & 12 \\
\hline art. 18c & - & 23 & 22 & 17 & 13 \\
\hline Razem & - & - & 28 & 56 & 61 \\
\hline
\end{tabular}

Źródło: opracowanie własne na podstawie danych pochodzących z (Sprawozdanie... 2011-2016).

na złamaniu przepisów art. 18, ust. 1 tej ustawy. W analizowanym okresie ich liczba wynosiła 919. Oznacza to, że ujawniono nieprawidłowości polegające na zaniechaniu przeprowadzenia lub rozliczenia procesu inwentaryzacji. Dużo takich przypadków miało miejsce w 2011 r. (23,4\%), a ich najmniejszą liczbę odnotowano 
w 2015 r. (8,2\%), tylko 5 było natomiast związanych z nieposzanowaniem art. 12 . Można więc uznać, że w okresie objętym badaniem sporadycznie ujawniano nieprawidłowości w gospodarce finansowej jednostek sektora finansów publicznych polegające na przeznaczeniu środków rezerwy na inny cel, niż został określony w decyzji o ich przyznaniu.

Podsumowując rozważania dotyczące deliktów z zakresu dyscypliny finansów publicznych, można uznać, że wśród popełnianych czynów przeważają te polegające na błędnym wydatkowaniu środków publicznych: bez upoważnienia, $\mathrm{z}$ przekroczeniem uprawnień (określonych $w$ uchwale budżetowej lub planie finansowym) albo z naruszeniem reguł i innych przepisów w zakresie dokonywania poszczególnych rodzajów wydatków budżetowych.

\section{Sankcje za nieprzestrzeganie zasad dyscypliny finansów publicznych}

Celem wprowadzenia zasad dotyczących dyscypliny finansów publicznych było uzyskanie możliwości prawnego wpływania przez właściwe organy państwa na jakość i efektywność zarządzania gospodarką budżetową. Bez możliwości nakładania określonych sankcji na osoby dopuszczające się naruszeń system dochodzenia odpowiedzialności za nieprzestrzeganie dyscypliny finansów publicznych nie spełniałby swojej funkcji. Aby skutecznie zapobiegać przypadkom uporczywego ignorowania reguł dyscypliny finansów publicznych, ustawodawca wprowadził do systemu prawno-finansowego konkretne sankcje. Opisy poszczególnych rodzajów kar zawarto w Ustawie z dnia 17 grudnia 2004 r. (zob. Dębowska-Sołtyk i Sołtyk 2015, s. 45). Wyróżniono cztery ich rodzaje: upomnienie, naganę, karę pieniężną oraz karę zakazu pełnienia funkcji związanych z dysponowaniem środkami publicznymi, najbardziej restrykcyjną. W ustawie nie sformułowano wprost obowiązku stopniowania kar (wymierzania ich w kolejności od najłagodniejszej do najsurowszej), stwierdzono jednak, że w wypadku najlżejszych przewinień powinno zostać zastosowane upomnienie, nagana natomiast, kara pieniężna oraz zakaz pełnienia funkcji związanych z dysponowaniem środkami publicznymi w razie cięższych naruszeń dyscypliny, szczególnie zagrażających stabilności finansów publicznych (Lipiec-Warzecha 2012, s. 398).

Najniższą karą, a więc najmniej dotkliwą dla osoby ukaranej, jest kara upomnienia. Może ona zostać wymierzona, gdy stopień szkodliwości naruszenia dyscypliny finansów publicznych nie jest znaczny. Kara ta jest swoistym ostrzeżeniem, mającym na celu zapobieżenie ponownemu naruszeniu przez obwinionego dyscypliny finansów publicznych (Orzeczenie GKO z 13 stycznia 2003 r. ..., za: Lipiec-Warzecha 2012, s. 427). Z danych zawartych w tabeli 2 wynika, że kara 
upomnienia była najczęściej wymierzana przez RKO. Jej udział w orzeczonych karach ogółem wynosił 87\% w 2011 r. oraz 80\% w 2016 r., co może świadczyć o uwzględnianiu przez RKO okoliczności wskazujących na nieznaczny stopień szkodliwości popełnionego czynu lub dotychczasowej niekaralności osoby, na którą kara ta została nałożona.

Tabela 2. Kary wymierzone przez RKO w latach 2011-2016

\begin{tabular}{|l|c|c|c|c|c|c|}
\hline \multicolumn{1}{|c|}{ Wyszczególnienie } & 2011 & 2012 & 2013 & 2014 & 2015 & 2016 \\
\hline Ogółem & 373 & 396 & 291 & 299 & 323 & 295 \\
\hline Kara upomnienia & 327 & 347 & 253 & 260 & 266 & 239 \\
\hline Kara nagany & 40 & 42 & 28 & 32 & 47 & 39 \\
\hline Kara pieniężna & 6 & 7 & 9 & 7 & 9 & 17 \\
\hline $\begin{array}{l}\text { Kara przewidziana w art. 31, ust. 1, pkt 4 Ustawy } \\
\text { z dnia 17 grudnia 2004 r. }\end{array}$ & - & - & 1 & - & 1 & - \\
\hline
\end{tabular}

Źródło: opracowanie własne na podstawie danych pochodzących z (Sprawozdanie... 2011-2016).

Surowszą karą jest nagana, ma ona bowiem konkretne skutki prawne związane z ujemną lub negatywną oceną kwalifikacyjną skazanego. W orzeczeniu GKO stwierdzono, że „przy umyślnym naruszeniu dyscypliny finansów publicznych wymierza się karę nagany lub wyższą" (Orzeczenie GKO z 14 lipca 2011 r. ...). W analizowanym okresie RKO dość rzadko wymierzały karę nagany. Jej udział w orzeczonych karach ogółem wynosił: 10,7\% w 2011 r., 9,6\% w 2013 r., $14,5 \%$ w 2015 r. oraz $13,2 \%$ w 2016 r.

Gdy stopień szkodliwości naruszenia dyscypliny finansów publicznych jest znaczny, RKO może nałożyć na obwinionego karę pieniężną. Jest ona orzekana obligatoryjnie wskutek naruszeń polegających na tym, że (art. 34a Ustawy z dnia 17 grudnia 2004 r....):

- nie zostały wpłacone lub zwrócone należności Skarbu Państwa, jednostki samorządu terytorialnego lub innej jednostki sektora finansów publicznych w znacznej wysokości,

- bez upoważnień albo z przekroczeniem zakresu upoważnień zaciągnięto zobowiązanie finansowe lub dokonano wydatku w znacznej wysokości,

- zapłacono ze środków publicznych odsetki, kary lub opłaty albo oprocentowanie w znacznej wysokości,

- złożono zamówienie publiczne z istotnym naruszeniem zasady uczciwej konkurencji lub zasady równego traktowania wykonawców.

Kara pieniężna jest środkiem sanacyjnym i dyscyplinującym, nie ma charakteru odszkodowawczego - jest płatna do budżetu państwa i stanowi jego dochód 
(zob. Lipiec-Warzecha 2012, s. 398). W latach 2011-2016 kara pieniężna była wymierzana przez RKO sporadycznie. W 2016 r. jej udział w orzeczonych karach ogółem stanowił jedynie 5,7\%. Również we wcześniejszych latach stanowiła ona nieznaczną część orzeczonych kar: 1,6\% w 2011 r., 1,7\% w 2012 r. oraz 3\% w 2013 r. Średnia wysokość wymierzanej kary pieniężnej w latach 2013-2016 wynosiła jedynie 3849,30 zł. Biorąc pod uwagę zasady ustalania kary pieniężnej wynikające z treści art. 31, ust. 2 i 3 Ustawy z dnia 17 grudnia 2004 r. - a także wysokość średniej wymierzanej kary pieniężnej, można uznać, że nie jest ona zbyt dotkliwa dla sprawców naruszających reguły legalnego gospodarowania środkami publicznymi.

Najbardziej restrykcyjna jest kara zakazu pełnienia funkcji związanych z dysponowaniem środkami publicznymi. Właściwy organ orzekający może wymierzyć ten rodzaj kary na okres od roku do pięciu lat. Uwzględniając konsekwencje prawne, jakie ponosi osoba, wobec której orzeczono ten rodzaj sankcji, należy uznać, że niewątpliwie jest ona najsurowszą karą, jaką można wymierzyć za naruszenie dyscypliny finansów publicznych. $Z$ danych liczbowych zawartych w tabeli 2 wynika, że kara zakazu pełnienia funkcji związanych $\mathrm{z}$ dysponowaniem środkami publicznymi nie jest wymierzana często.

W okresie objętym badaniem RKO jedynie dwukrotnie zwolniła, na czas określony w orzeczeniu, z pełnienia funkcji kierownika oraz zastępcy kierownika bezpośredniego za wykonanie budżetu lub planu finansowego: w 2011 r. i w 2015 r. Zakaz pełnienia funkcji związanych $\mathrm{z}$ dysponowaniem środkami publicznymi wydaje się odpowiednim instrumentem prawnym służącym do zapewnienia optymalnego zarządzania finansami publicznymi, prowadzi bowiem do usunięcia z zajmowanych stanowisk, związanych z odpowiedzialnością za finanse publiczne, osób, których taka odpowiedzialność nie cechuje (zob. Lipiec-Warzecha 2012, s. 405).

Przepisy Ustawy z dnia 17 grudnia 2004 r. zawierają zasadę swobody wymierzania kary przez RKO. Należy jednak zaznaczyć, że: „,swoboda ta nie oznacza dowolności. Organ orzekający, wymierzając karę, winien uwzględnić nie tylko stopień winy sprawcy oraz skutki jego czynu. Winien także uwzględniać stopień szkodliwości czynu dla finansów publicznych oraz cele kary. Zarówno kara zbyt surowa, jak i zbyt łagodna, spodziewanego skutku nie może wywrzeć. Kara zbyt surowa, której efekty odczuwać będzie ukarany, będzie uważana przez niego za karę niesprawiedliwą. A zatem, aby wymierzyć karę sprawiedliwą, należy dokonać wnikliwej analizy wagi naruszonych obowiązków, sposób i okoliczności ich naruszenia oraz skutki naruszenia" (Orzeczenie GKO z 30 lipca 2012 r....). 


\section{Działalność RKO jako organu właściwego w sprawach oceny naruszeń dyscypliny finansów publicznych - wybrane zagadnienia}

Jednym z rodzajów komisji ustawowo uprawnionych do orzekania w sprawach naruszeń dyscypliny finansów publicznych są RKO. Zasięg terytorialny RKO jest zbieżny z obrębem działania regionalnej izby obrachunkowej, przy której została utworzona. Siedziby izb zostały wyznaczone w rozporządzeniu Prezesa Rady Ministrów (Rozporządzenie Prezesa Rady Ministrów z dnia 16 lipca 2004 r. ...). W ujęciu podmiotowym zakres uprawnień RKO obejmuje dwa istotne segmenty sektora finansów publicznych: jednostki samorządu terytorialnego oraz wojewodów wraz z podległymi im jednostkami (zob. Misiąg 2017, s. 1208). Do kompetencji orzeczniczych RKO należy zaliczyć także wydawanie orzeczeń w sprawie innych jednostek otrzymujących do dyspozycji środki publiczne, przekazane z budżetów samorządowych lub innych środków publicznych, takich jak stowarzyszenia oraz fundacje, które dysponują publicznymi środkami finansowymi (datacjami celowymi) przekazanymi na realizację zadań publicznych.

Uprawnienia orzecznicze komisji obejmują także czynności polegające na rozpatrywaniu wniosków dotyczących możliwego naruszenia dyscypliny finansów publicznych w odniesieniu do podmiotów, których zasady tworzenia oraz likwidacji nie zostały określone w ustawie o finansach publicznych, lecz w odrębnych ustawach. Są to: samorządowe samodzielne publiczne zakłady opieki zdrowotnej, samorządowe instytucje kultury oraz wojewódzkie ośrodki ruchu drogowego. RKO nie orzekają odnośnie do osób pełniących funkcję marszałka województwa, członka zarządu województwa i głównego księgowego budżetu województwa. Wobec tych osób postępowanie prowadzone jest przed Resortową Komisją Orzekającą utworzoną przy ministrze ds. administracji publicznej (zob. Walczak 2012, s. 311).

W analizie działalności RKO uwzględniono wybrane aspekty, obejmujące takie kwestie, jak:

- przypisane czyny naruszeń,

- złożone wnioski o ukaranie,

- odstąpienia od wymierzenia kary,

- orzeczenia o uniewinnieniu,

- werdykty o ukaraniu obwinionego.

W latach 2011-2016 liczba przypisanych czynów naruszających dyscyplinę finansów publicznych była zróżnicowana. Najwięcej z nich odnotowano w 2012 r. (1633), najmniej zaś w 2014 r. (915). Tak duży spadek tej liczby można uzasadnić m.in. uwzględnieniem koncepcji kontroli zarządczej w administracji publicznej. Jej podstawowym celem jest indywidualizacja odpowiedzialności, co umożliwia nałożenie sankcji karnej lub dyscyplinarnej za naruszenie dyscypliny finansów publicznych. W analizowanym okresie przypisano obwinionym popełnienie 7170 
czynów (średnio 1195 rocznie). Najwięcej czynów ujawniono w RKO Kielce: 219, co stanowiło 13,4\% czynów ogółem w 2012 r. Najmniej odnotowano w RKO Białystok: 4, tj. 0,3\% wszystkich czynów w 2013 r. Szczegółowe dane dotyczące przypisanych czynów naruszeń dyscypliny finansów publicznych w poszczególnych RKO przedstawiono w tabeli 3.

Tabela 3. Przypisane czyny naruszeń dyscypliny finansów publicznych w latach 2011-2016

\begin{tabular}{|l|c|c|c|c|c|c|}
\hline Wyszczególnienie & 2011 & 2012 & 2013 & 2014 & 2015 & 2016 \\
\hline Ogółem & 1589 & 1633 & 1126 & 915 & 981 & 926 \\
\hline Białystok & 71 & 42 & 4 & 10 & 20 & 14 \\
\hline Bydgoszcz & 20 & 36 & 26 & 15 & 24 & 42 \\
\hline Gdańsk & 199 & 150 & 48 & 97 & 75 & 59 \\
\hline Katowice & 128 & 118 & 102 & 56 & 71 & 51 \\
\hline Kielce & 167 & 219 & 132 & 67 & 82 & 51 \\
\hline Kraków & 165 & 170 & 100 & 100 & 80 & 100 \\
\hline Lublin & 56 & 166 & 85 & 47 & 58 & 90 \\
\hline Łódź & 65 & 67 & 79 & 45 & 66 & 68 \\
\hline Olsztyn & 121 & 108 & 60 & 86 & 97 & 97 \\
\hline Opole & 47 & 55 & 67 & 43 & 47 & 79 \\
\hline Poznań & 199 & 170 & 98 & 90 & 121 & 84 \\
\hline Rzeszów & 95 & 124 & 134 & 68 & 42 & 13 \\
\hline Szczecin & 33 & 40 & 44 & 22 & 49 & 42 \\
\hline Warszawa & 183 & 115 & 80 & 102 & 78 & 71 \\
\hline Wrocław & 22 & 31 & 32 & 37 & 52 & 43 \\
\hline Zielona Góra & 18 & 22 & 35 & 30 & 19 & 22 \\
\hline
\end{tabular}

Źródło: opracowanie własne na podstawie danych pochodzących z (Sprawozdanie... 2011-2016).

Podstawą do wszczęcia postępowania w sprawach naruszeń dyscypliny finansów publicznych jest wniosek o ukaranie. Jedynym uprawnionym organem do wystąpienia z wnioskiem jest rzecznik dyscypliny finansów publicznych, który w toku postępowania pełni jednocześnie funkcję oskarżyciela. Sporządzony wniosek o ukaranie podlega weryfikacji w dalszych etapach postępowania przed właściwą komisją orzekającą (zob. Sołtyk 2017, s. 1309). Z orzeczenia GKO wydanego 16 grudnia 2010 r. wynika, że: „o zakresie postępowania w sprawach o naruszenie dyscypliny finansów publicznych decyduje podmiot uprawniony do złożonego wniosku o ukaranie. Komisja orzekająca może rozpoznać sprawę jedynie w zakresie określonym we wniosku o ukaranie" (Orzeczenie GKO z 16 grudnia 
2010 r....). W latach 2011-2016 do RKO w Polsce zostało złożonych łącznie 6709 wniosków o ukaranie, czyli średnio 70 na RKO. Najwięcej wniosków wpłynęło do RKO w Poznaniu (824), na drugim miejscu była RKO Kraków (785), a na trzecim, z niewielką różnicą, RKO Katowice (774). Największa liczba wniosków o ukaranie została złożona w 2011 r. do RKO w Krakowie (263, co stanowiło $18 \%$ wszystkich wniosków). Na drugim miejscu pod tym względem znalazła się RKO Poznań z liczbą 220 wniosków (15\%). Najmniej wniosków złożono do RKO Zielona Góra (112), a także do RKO Białystok (113). Dane dotyczące liczby wniosków o ukaranie złożonych do poszczególnych RKO w Polsce przedstawiono w tabeli 4.

Tabela 4. Wnioski o ukaranie złożone w latach 2011-2016

\begin{tabular}{|l|c|c|c|c|c|c|}
\hline Wyszczególnienie & 2011 & 2012 & 2013 & 2014 & 2015 & 2016 \\
\hline Ogółem & 1475 & 1165 & 1020 & 926 & 1070 & 1053 \\
\hline Białystok & 44 & 22 & 10 & 10 & 16 & 11 \\
\hline Bydgoszcz & 95 & 68 & 60 & 43 & 63 & 51 \\
\hline Gdańsk & 89 & 85 & 68 & 70 & 107 & 51 \\
\hline Katowice & 125 & 169 & 130 & 140 & 108 & 102 \\
\hline Kielce & 111 & 82 & 55 & 60 & 19 & 40 \\
\hline Kraków & 263 & 114 & 104 & 81 & 126 & 97 \\
\hline Lublin & 51 & 60 & 73 & 52 & 52 & 87 \\
\hline Łódź & 75 & 79 & 65 & 41 & 57 & 78 \\
\hline Olsztyn & 64 & 54 & 39 & 64 & 94 & 75 \\
\hline Opole & 76 & 44 & 64 & 45 & 38 & 64 \\
\hline Poznań & 220 & 156 & 103 & 111 & 121 & 113 \\
\hline Rzeszów & 83 & 51 & 43 & 35 & 45 & 53 \\
\hline Szczecin & 79 & 56 & 63 & 52 & 44 & 76 \\
\hline Warszawa & 61 & 67 & 89 & 54 & 68 & 67 \\
\hline Wrocław & 23 & 35 & 25 & 53 & 69 & 72 \\
\hline Zielona Góra & 16 & 23 & 29 & 15 & 13 & 16 \\
\hline
\end{tabular}

Źródło: opracowanie własne na podstawie danych pochodzących z (Sprawozdanie... 2011-2016).

Ustawodawca dał komisjom orzekającym prawo do zastosowania dobrodziejstwa polegającego na złagodzeniu wnioskowanej przez oskarżyciela kary albo nawet odstąpieniu od jej wymierzenia. W orzeczeniu GKO z 26 lipca 2004 r. podkreślono, że „odstąpienie od wymierzenia kary nie jest równoznaczne z uniewinnieniem" (Orzeczenie GKO z 26 lipca 2004 r. ...). Przesłanką do podjęcia decyzji o odstąpieniu od wymierzenia kary może być wzorowe wypełnianie przez 
obwinionego obowiązków służbowych przed popełnieniem czynu naruszającego dyscyplinę finansów publicznych. Istotne jest także to, do jak dużego uszczerbku doszło w wyniku jej naruszenia. W latach 2011-2016 RKO w Polsce wydały łącznie 2446 orzeczeń o odstąpieniu od wymierzenia kary, z czego największa liczba takich werdyktów zapadła w 2011 r. (522). Najwięcej tego rodzaju orzeczeń wydała RKO Kraków: 111, co stanowiło $21,2 \%$ wszystkich werdyktów o odstąpieniu od wymierzenia kary. Należy podkreślić, że również w pozostałych latach RKO w Krakowie bardzo często stosowała takie rozwiązania prawne w tym względzie. Najrzadziej z tej możliwości korzystano w RKO Zielona Góra (29), a także w RKO Białystok (38). Szczegółowe dane liczbowe dotyczące werdyktów o odstąpieniu od wymierzenia kary przedstawiono w tabeli 5.

Tabela 5. Odstąpienia od wymierzenia kary w latach 2011-2016

\begin{tabular}{|l|c|c|c|c|c|c|}
\hline Wyszczególnienie & 2011 & 2012 & 2013 & 2014 & 2015 & 2016 \\
\hline Ogółem & 522 & 448 & 348 & 364 & 364 & 400 \\
\hline Białystok & 17 & 5 & 2 & 5 & 2 & 7 \\
\hline Bydgoszcz & 9 & 7 & 11 & 9 & 10 & 16 \\
\hline Gdańsk & 39 & 22 & 19 & 39 & 35 & 24 \\
\hline Katowice & 56 & 67 & 57 & 32 & 32 & 41 \\
\hline Kielce & 25 & 35 & 8 & 30 & 17 & 21 \\
\hline Kraków & 111 & 70 & 47 & 58 & 44 & 39 \\
\hline Lublin & 23 & 29 & 23 & 17 & 29 & 53 \\
\hline Łódź & 26 & 37 & 31 & 19 & 21 & 28 \\
\hline Olsztyn & 40 & 18 & 10 & 27 & 20 & 22 \\
\hline Opole & 25 & 33 & 38 & 15 & 22 & 34 \\
\hline Poznań & 61 & 57 & 33 & 37 & 47 & 24 \\
\hline Rzeszów & 32 & 19 & 21 & 12 & 17 & 7 \\
\hline Szczecin & 17 & 13 & 12 & 8 & 14 & 14 \\
\hline Warszawa & 34 & 19 & 18 & 34 & 25 & 39 \\
\hline Wrocław & 4 & 14 & 12 & 17 & 25 & 23 \\
\hline Zielona Góra & 3 & 6 & 5 & 4 & 8 \\
\hline
\end{tabular}

Źródło: opracowanie własne na podstawie danych pochodzących z (Sprawozdanie... 2011-2016).

Regulacje prawne umożliwiają RKO uniewinnienie posądzonego. Katalog przesłanek, które są brane pod uwagę podczas oceny przypisanego czynu naruszenia dyscypliny finansów publicznych, jest zawarty w art. 78 Ustawy z dnia 17 grudnia 2004 r. Z analizy orzecznictwa komisji wynika, że często podstawą do sformułowania werdyktu o uniewinnieniu jest niepopełnienie przez 
posądzonego zarzucanego mu czynu lub brak faktycznych i prawnych znamion naruszenia dyscypliny finansów publicznych. Na konieczność naruszenia konkretnego przepisu prawa, tj. art. 5-18c Ustawy z dnia 17 grudnia 2004 r., zwrócono uwagę w orzeczeniu GKO z 28 marca 2011 r., uznając, że „do przypisania odpowiedzialności za naruszenie dyscypliny finansów publicznych konieczne jest zarówno formalne naruszenie przepisu prawa, ale także udowodnienie winy po stronie konkretnego sprawcy" (Orzeczenie GKO z 28 marca 2011 r. ...). Liczba orzeczeń o uniewinnieniu nie jest zbyt duża: 1518 . Oznacza to, że średnio w ciągu roku RKO wydawały 253 takie werdykty. Spośród wszystkich regionalnych komisji w Polsce na pierwszym miejscu, jeśli chodzi o podejmowanie decyzji o uniewinnieniu, znalazła się RKO Katowice (317 werdyktów), a na drugim miejscu wymienić należy RKO Poznań (193). Bardzo małą liczbę takich decyzji wydano natomiast w RKO Zielona Góra (16), a także RKO Białystok (35). Szczegółowe dane dotyczące liczby podjętych decyzji o uniewinnieniu w sprawach o naruszenie dyscypliny finansów publicznych przedstawiono w tabeli 6 .

Tabela 6. Orzeczenia o uniewinnieniu wydane w latach 2011-2016

\begin{tabular}{|l|c|c|c|c|c|c|}
\hline Wyszczególnienie & 2011 & 2012 & 2013 & 2014 & 2015 & 2016 \\
\hline Ogółem & 247 & 300 & 247 & 248 & 229 & 247 \\
\hline Białystok & 6 & 10 & 7 & 4 & 4 & 4 \\
\hline Bydgoszcz & 17 & 29 & 28 & 22 & 22 & 20 \\
\hline Gdańsk & 10 & 17 & 23 & 19 & 24 & 22 \\
\hline Katowice & 45 & 73 & 38 & 65 & 52 & 44 \\
\hline Kielce & 10 & 14 & 9 & 6 & 9 & 7 \\
\hline Kraków & 19 & 23 & 10 & 10 & 16 & 19 \\
\hline Lublin & 11 & 11 & 9 & 25 & 2 & 15 \\
\hline Łódź & 17 & 25 & 14 & 9 & 12 & 13 \\
\hline Olsztyn & 7 & 2 & 2 & 4 & 12 & 9 \\
\hline Opole & 10 & 15 & 15 & 10 & 6 & 5 \\
\hline Poznań & 42 & 39 & 38 & 25 & 25 & 24 \\
\hline Rzeszów & 12 & 7 & 9 & 5 & 11 & 32 \\
\hline Szczecin & 28 & 11 & 22 & 16 & 8 & 11 \\
\hline Warszawa & 5 & 16 & 4 & 13 & 6 & 12 \\
\hline Wrocław & 3 & 7 & 13 & 12 & 19 & 10 \\
\hline Zielona Góra & 5 & 1 & 6 & 3 & 1 & 0 \\
\hline
\end{tabular}

Źródło: opracowanie własne na podstawie danych pochodzących z (Sprawozdanie... 2011-2016). 
W praktyce zarządzania finansami publicznymi ujawniają się różnej wagi nieprawidłowości w gospodarce budżetowej. Ujawnienie negatywnych zjawisk powinno wiązać się z koniecznością poniesienia odpowiedzialności. W sferze budżetowej odpowiedzialność za podjęte decyzje, tak samo jak za niewykonanie określonego typu działań zmierzających do realizacji zadania, ponosi kierownik jednostki, a także pracownicy - na podstawie udzielonych im upoważnień (zob. Dylewski, Filipiak i Gorzałczyńska-Koczkodaj 2006, s. 44). Jednym ze sposobów ograniczenia naruszeń dyscypliny finansów publicznych jest wprowadzenie odrębnego systemu wymierzania kar (zob. Kosikowski 2006, s. 4). Komisja orzekająca, podejmując decyzję o ukaraniu obwinionego, uwzględnia przede wszystkim wagę naruszeń dyscypliny finansów publicznych, a także rozmiar wyrządzonej szkody materialnej. W latach 2011-2016 RKO w Polsce podjęły w sumie 1977 decyzji o ukaraniu obwinionego. Najczęściej werdykty o ukaraniu zapadały w RKO Poznań (296), a także RKO Warszawa (214), najrzadziej zaś w RKO Bydgoszcz (47). W tabeli 7 zestawiono szczegółowe dane o liczbie osób ukaranych przez poszczególne RKO w Polsce.

Tabela 7. Liczba osób ukaranych przez poszczególne RKO w latach 2011-2016

\begin{tabular}{|l|c|c|c|c|c|c|}
\hline Wyszczególnienie & 2011 & 2012 & 2013 & 2014 & 2015 & 2016 \\
\hline Ogółem & 373 & 396 & 291 & 299 & 323 & 295 \\
\hline Białystok & 22 & 13 & 1 & 4 & 11 & 4 \\
\hline Bydgoszcz & 4 & 13 & 7 & 3 & 10 & 10 \\
\hline Gdańsk & 21 & 56 & 17 & 38 & 29 & 24 \\
\hline Katowice & 27 & 35 & 25 & 16 & 16 & 5 \\
\hline Kielce & 27 & 11 & 14 & 11 & 10 & 6 \\
\hline Kraków & 13 & 32 & 19 & 14 & 17 & 34 \\
\hline Lublin & 7 & 9 & 21 & 17 & 14 & 20 \\
\hline Łódź & 19 & 14 & 20 & 14 & 23 & 17 \\
\hline Olsztyn & 25 & 40 & 27 & 33 & 51 & 48 \\
\hline Opole & 16 & 18 & 13 & 12 & 17 & 25 \\
\hline Poznań & 86 & 60 & 35 & 37 & 36 & 42 \\
\hline Rzeszów & 31 & 18 & 14 & 16 & 15 & 4 \\
\hline Szczecin & 7 & 18 & 24 & 11 & 24 & 19 \\
\hline Warszawa & 50 & 38 & 33 & 48 & 27 & 18 \\
\hline Wrocław & 10 & 9 & 10 & 9 & 14 & 14 \\
\hline Zielona Góra & 12 & 11 & 16 & 9 & 8 \\
\hline
\end{tabular}

Źródło: opracowanie własne na podstawie danych pochodzących z (Sprawozdanie... 2011-2016). 


\section{Podsumowanie}

Zarządzanie finansami publicznymi wymaga wypracowania skutecznych mechanizmów kontrolnych redukujących ryzyko wystąpienia nieprawidłowości i marnotrawstwa. Bez wątpienia ważną rolę w zapewnieniu legalnego gospodarowania środkami publicznymi odgrywa odrębny aparat orzeczniczy - RKO, gwarantujące skuteczność działań kontrolnych uprawnionych do tego organów i instytucji. Działalność RKO jest również źródłem orzecznictwa, wskazującego na właściwe rozpoznanie i rozumienie przepisów dotyczących zarządzania finansami państwa dzięki temu, że odnosi się nie tylko do legalności, ale też do skutków określonych działań lub zaniechań dla dyscypliny finansów publicznych (Winiarz 2011, s. 349).

Tylko nieliczna część wniosków skierowanych przez oskarżyciela (rzecznika dyscypliny) zostaje, niestety, uznana przez członków RKO za podstawę do wymierzenia stosownej sankcji. Wśród orzeczonych kar przeważa kara upomnienia, co wywołuje uzasadnione obawy dotyczące celowości kar. Bez wątpienia podstawowym celem nakładania kary są działania prewencyjne. Istotne jest także kształtowanie właściwych postaw społecznych. $Z$ analizy danych wynika jednak, że pełnienie przez system odpowiedzialności za naruszenie dyscypliny finansów publicznych funkcji represyjnej jest wątpliwe. Działalność RKO ma natomiast bez wątpienia wpływ na prawidłowe zarządzanie operacjami finansowymi. Wydane orzeczenia oraz odpowiedzi na indywidualne interpelacje decydentów wyraźnie wpisują się w nurt projektowania systemu kontroli zarządczej, czyli zgodnie z ustawą - ,zapewnienia działania jednostki w sposób zgodny z prawem”.

\section{Literatura}

Chojna-Duch E. (2003), Polskie prawo finansowe. Finanse publiczne, Wydawnictwo Prawnicze LexisNexis, Warszawa.

Dekret z dnia 17 grudnia 1952 r. o uchwaleniu i wykonywaniu budżetu państwa, Dz.U. nr 50, poz. 334, z późn. zm.

Dębowska-Sołtyk M., Sołtyk P. (2012), Kary za naruszenie dyscypliny finansów publicznych jako skutek dysfunkcji gospodarowania środkami publicznymi, ,Finanse Komunalne", nr 5.

Dylewski M., Filipiak B., Gorzałczyńska-Koczkodaj M. (2006), Finanse samorzqdowe. Narzędzia, decyzje, procesy, Wydawnictwo Naukowe PWN, Warszawa.

Kosikowski C. (2006), Odpowiedzialność za naruszenie reżimu prawnego finansów publicznych (nowa koncepcja), „Państwo i Prawo”, nr 12.

Kot J. (2011), Wstęp do monografii pokonferencyjnej (w:) Dyscyplina finansów publicznych - stan obecny i kierunki zmian, red. M. Smaga, M. Winiarz, Grupa Ergo, Wrocław. 
Lipiec-Warzecha L. (2012), Odpowiedzialność za naruszenie dyscypliny finansów publicznych. Komentarz, Wolters Kluwer, Warszawa.

Malinowska-Misiąg E., Misiąg W. (2006), Finanse publiczne w Polsce, LexisNexis, Warszawa-Rzeszów.

Misiąg W. (2017), Komisje orzekajq̨ce i ich właściwość (w:) Ustawa o finansach publicznych, Ustawa o odpowiedzialności za naruszenie dyscypliny finansów publicznych. Komentarz, red. W. Misiąg, Wydawnictwo C.H. Beck, Warszawa.

Orzeczenie Głównej Komisji Orzekającej w Sprawach o Naruszenie Dyscypliny Finansów Publicznych z 13 stycznia 2003 r., DF/GKO/Odw.-100/131-132/2002.

Orzeczenie Głównej Komisji Orzekającej w Sprawach o Naruszenie Dyscypliny Finansów Publicznych z 26 lipca 2004 r., DF/GKO/Odw.-32/43-45/RN-10-12/2004/521.

Orzeczenie Głównej Komisji Orzekającej w Sprawach o Naruszenie Dyscypliny Finansów Publicznych z 16 grudnia 2010 r., BDF1/ 4900/95/106/10/05, Legalis.

Orzeczenie Głównej Komisji Orzekającej w Sprawach o Naruszenie Dyscypliny Finansów Publicznych z 28 lutego 2011 r., BDF1/4900/78/89/10/2215, Biuletyn orzecznictwa w sprawach o naruszenie dyscypliny finansów publicznych 2011, nr 2, poz. 10.

Orzeczenie Głównej Komisji Orzekającej w Sprawach o Naruszenie Dyscypliny Finansów Publicznych z 28 marca 2011 r., BDF1/4900/10/11/11/432, Lex nr 798193.

Orzeczenie Głównej Komisji Orzekającej w Sprawach o Naruszenie Dyscypliny Finansów Publicznych z 14 lipca 2011 r., BDFP1/4900/55/61/11/29, Lex nr 102784.

Orzeczenie Głównej Komisji Orzekającej w Sprawach o Naruszenie Dyscypliny Finansów Publicznych z 30 lipca 2012 r., BDF1/4900/7/6/12/121, Lex nr 1224841.

Owsiak S. (2013), Finanse publiczne. Teoria i praktyka, Wydawnictwo Naukowe PWN, Warszawa.

Rozporządzenie Prezesa Rady Ministrów z dnia 16 lipca 2004 r. w sprawie siedziby i zasięgu terytorialnego regionalnych izb obrachunkowych oraz szczegółowej organizacji izb, liczby członków i trybu postępowania, Dz.U. z 2014 r., nr 167, poz. 1747.

Sołtyk P. (2017), Wniosek o ukaranie (w:) Ustawa o finansach publicznych. Ustawa o odpowiedzialności za naruszenie dyscypliny finansów publicznych. Komentarz, red. W. Misiąg, Wydawnictwo C.H. Beck, Warszawa.

Sprawozdanie z działalności Głównej Komisji Orzekająej w Sprawach o Naruszenie Dyscypliny Finansów Publicznych oraz zbiorcze sprawozdanie z działalności komisji orzekajqcych w pierwszej instancji, sprawozdania z lat 2011-2016.

Szołno-Koguc J. (2015), Dyscyplina finansów publicznych - refleksje w świetle dotychczasowych doświadczén (w:) 10 lat ustawy o odpowiedzialności za naruszenie dyscypliny finansów publicznych, Biuletyn orzecznictwa w sprawach o naruszenie dyscypliny finansów publicznych - wydanie specjalne, red. W. Robaczyński, A. Talik, Z. Zieliński, Warszawa.

Uchwała nr 23 Rady Ministrów z dnia 29 kwietnia 1953 r. o zasadach i trybie wykonania budżetu państwa, M.P. nr A-53, poz. 592, z późn. zm.

Ustawa z dnia 1 lipca 1958 r. o prawie budżetowym, Dz.U. nr 45, poz. 221, z późn. zm.

Ustawa z dnia 25 listopada 1970 r. Prawo budżetowe, Dz.U. nr 29, poz. 244, z późn. zm.

Ustawa z dnia 3 grudnia 1984 r. Prawo budżetowe, Dz.U. nr 56, poz. 283, z późn. zm.

Ustawa z dnia 5 stycznia 1991 r. Prawo budżetowe, t.j., Dz.U. nr 72, poz. 344, z późn. zm.

Ustawa z dnia 26 listopada 1998 r. o finansach publicznych, t.j., Dz.U. 2003, nr 15, poz. 148 , z późn. zm. 
Ustawa z dnia 17 grudnia 2004 r. o odpowiedzialności za naruszenie dyscypliny finansów publicznych, t.j., Dz.U. 2013, poz. 168.

Walczak P. (2012), Odpowiedzialność w ramach dyscypliny finansów publicznych i kontroli zarzqdczej (w:) Odpowiedzialność urzędnika administracji publicznej, red. J. Borkowska, Wydawnictwo C.H. Beck, Warszawa.

Winiarz M. (2011), Ochrona prawidłowości gospodarowania środkami publicznymi w samorzqdzie na przykładzie Regionalnej Komisji Orzekajqcej w sprawach o naruszenie dyscypliny finansów publicznych przy Regionalnej Izbie Obrachunkowej w Krakowie, ,Zeszyty Naukowe Polskiego Towarzystwa Naukowego”, nr 10.

Ziółkowska W. (2012), Finanse publiczne. Teoria i zastosowanie, Wydawnictwo Wyższej Szkoły Bankowej, Poznań.

\section{The Importance of the Regional Arbitration Commission in the System of Liability for Breach of Public Finance Discipline}

(Abstract)

The article examines the activities of the regional arbitration commission (RAC) in the system of liability for breach of public finance discipline. It covers attributed acts of violations of public finance discipline, applications for punishment, derogations from punishment, verdicts of acquittal and verdicts of punishment of the accused.

The aim of the article is to present selected issues of RAC activities over the years 2011-2016. To this end, the subject literature, legal regulations and reports of the Main Arbitration Commission in cases of violation of public finance discipline are analysed.

Keywords: local government, discipline of public finance, abnormalities, regional arbitration commission. 